\title{
Article \\ The Influence of Sociodemographic Factors on Mobile Device Use among Young Children in Putrajaya, Malaysia
}

\author{
Nur Nabilah Abdullah ${ }^{1}$, Suziyani Mohamed ${ }^{2, * \mathbb{C}}$, Kamariah Abu Bakar ${ }^{2}$ and Noratiqah Satari ${ }^{3}$ \\ 1 Faculty of Education, Universiti Kebangsaan Malaysia, Bangi 43600, Malaysia; nurnabilah414@gmail.com \\ 2 Centre of Education and Community Well-Being, Faculty of Education, Universiti Kebangsaan Malaysia, \\ Bangi 43600, Malaysia; kamariah_abubakar@ukm.edu.my \\ 3 Faculty of Human Development, Universiti Pendidikan Sultan Idris, Tanjong Malim 34500, Malaysia; \\ atiqahsatari@upsi.edu.my \\ * Correspondence: suziyani@ukm.edu.my
}

Citation: Abdullah, N.N.; Mohamed, S.; Abu Bakar, K.; Satari, N. The Influence of Sociodemographic Factors on Mobile Device Use among Young Children in Putrajaya,

Malaysia. Children 2022, 9, 228.

https://doi.org/10.3390/

children 9020228

Academic Editor: Susan H. Yoon

Received: 10 January 2022

Accepted: 6 February 2022

Published: 8 February 2022

Publisher's Note: MDPI stays neutral with regard to jurisdictional claims in published maps and institutional affiliations.

Copyright: (C) 2022 by the authors. Licensee MDPI, Basel, Switzerland. This article is an open access article distributed under the terms and conditions of the Creative Commons Attribution (CC BY) license (https:// creativecommons.org/licenses/by/ $4.0 /)$.

\begin{abstract}
Technology is evolving rapidly around the world, and the use of mobile devices is increasing every day. Today, everyone owns a mobile device, including young children. Parents provide and allow young children to use mobile devices for various purposes. Due to the fact of these circumstances, children begin to become comfortable with the use of mobile devices, and they are prone to excessive use. Therefore, the purpose of this study was to examine the influence of sociodemographic factors on excessive mobile device use among young children. Sociodemographic variables, including the child's gender, the child's age when starting to use a mobile device, the parent's educational level, household income, type of application used, and the purpose of giving a mobile device to the child, were selected as predictive factors. A cross-sectional survey study design with a quantitative approach was conducted. A simple random sampling technique was employed, and a total of 364 parents completed the adapted questionnaire, namely, the Problematic Mobile Phone Use Scale (PMPUS). Data were statistically analyzed using descriptive and binary logistic regression analysis. The findings revealed that gender, age of the child when starting to use mobile devices, and purpose of parents providing mobile devices significantly contributed to $77.7 \%$ of the variance to make children users with a problem. However, the parent's educational level, household income, and type of application did not significantly contribute to the problem of mobile device use. Later, this study discusses the research implication, limitation, and recommendation for future research based on the finding.
\end{abstract}

Keywords: mobile device; young children; gadget

\section{Introduction}

Mobile devices with internet access are a vital tool for every individual regardless of social background due their functions that can facilitate daily life. By using a mobile device, tasks can be managed from home without having to meet others. This situation leads to changes in the way humans communicate, interact, and accomplish daily routines. As a result, human contact is diminishing as the opportunity to interact face to face is also reduced [1,2]. Today, everyone uses mobile devices for various purposes such as gaming, web surfing, social media, and online chats including children [3]. The use of mobile devices among young children is increasing every year [4,5]. This scenario had raised awareness among experts about the negative impact of the excessive use of mobile devices on children's development. Furthermore, young children are exposed to online activities and mobile device content [6-9].

It is suggested that the use of mobile devices by children be properly monitored by parents to avoid excessive use. Parents should implement strict rules in controlling the duration and purpose of use $[10,11]$. Today, children prefer to sit alone and preoccupy themselves with activities on mobile devices. They tend to spend more time interacting 
with digital screens rather than playing, interacting face to face, and being active [10,12]. If this scenario is not handled carefully, children may forget the fun of playing with family and friends. Meanwhile, play has proven to be effective in stimulating children's development across domains. Furthermore, poor quality time spent with family members and friends causes weakened family bonds $[10,13,14]$, contributing to behavioral problems $[15,16]$ and poor social-emotional competence $[17,18]$, social communication, and social interaction skills [15,18-20].

Interpersonal skills involve children's communication with others, which should involve eye communication, body position and movements, facial gestures and expressions, voice intonation, language, and listener interaction [21]. Scholars have emphasized the negative impact of mobile devices on children's interpersonal skills [22] as they lack opportunities to socialize with peers and family. Consequently, children have difficulty conveying the information that is in their minds. Without socializing, children cannot practice communication and interaction skills. Children are reported to have difficulty with eye contact, gestures, facial expressions, and voice intonation [23]. This, when prolonged, can cause children's communication process to be stunted at an early age, which, in turn, invites verbal skill problems [20,24].

A previous study found that there was a significant relationship between the duration of mobile device use with psychosocial effects and children's interaction with peers in preschool [25]. Children who use mobile devices for a longer period are often associated with behavioral problems in self-regulation [26] and have attention problems [27,28]. These children are prone to unstable emotional outbursts, exhibit impulsive behavior, experience emotional disturbances, become aggressive and misbehave [24], and have limited interaction with peers at school $[25,29]$.

Moreover, excessive use of mobile devices also contributes to poor social-emotional competence among young children due to the poorly nurtured stimuli [18,30]. Furthermore, online games encourage children to be individualistic and more likely to be selfish and less cooperative. If such personalities are adapted in real life, then children are less tolerant in society. They will also find it difficult to accept defeat or failure if participating in a competition and will try to dominate the competition. Children who are overly dependent on mobile devices are more likely to be angry, restless, and uncomfortable when they are unable to access the devices [31,32]. In addition, excessive mobile device use leads to a lack of prosocial behaviors in young children. Children are reported to have difficulty with daily interactions, cooperative skills, lack of empathy, and not helping others [15,27].

Other than negative effects, the proper use of mobile devices and technology will lead to positive outcomes that benefit children. Some studies stated the positive effects of mobile device use on educational attainment [30,33-36]. The use of mobile devices in the classroom can help attract and engage children in learning activities [30,34]. In addition, mobile devices help enhance children's learning motivation [35] and promote active involvement in the classroom [36,37]. In addition, mobile device use provides a positive effect in promoting healthy social-emotional development among young children [38].

Despite the positive and negative effects of mobile device use on young children's development, it is vital to identify the predictive factors that contribute to this situation. In Malaysia, there has been limited research conducted on mobile device use among young children $[39,40]$, especially on identifying predictive factors. The existing research focuses more on the impact of mobile device use on young children's communication [39], socialemotional development [38-40], physical activity [41], and eye health [42,43]. Therefore, this study aimed to examine the predictive factors that contribute to excessive mobile device use among young children.

\section{Literature Review and Hypothesis Development}

This research aimed to determine the contribution of the predictive factors to excessive mobile device use among young children. Sociodemographic variables, including the child's gender, the child's age when starting to use a mobile device, the parent's educational 
level, household income, type of applications used, and the purpose of giving a mobile device to the child, were selected as predictive factors. These variables were selected based on previous studies [3,21,32,44-47].

Several studies reported a significant positive association between girls and problematic mobile device usage [48-55]. Contrasting this, several studies documented a significant positive association between boys and problematic mobile device usage [56] or revealed higher scores in boys than in girls $[32,44,45,57]$. Yet, some studies show gender is not a predictive factor of problematic use of mobile devices [3,58,59]. Girls and boys have different preferences for mobile device activities [48]. Girls likely spend time on learning activities [31], communication, and social networking applications [44,60]. Meanwhile, boys are keener on video gaming and television viewing [44,48].

The parent's educational level significantly contributes to problematic mobile device use as reported in $[53,58,61,62]$. Parents with lower educational levels tend to allow their children to spend extra time on a mobile device compared to parents with higher educational levels [22,62-65]. Parents with higher educational levels are more aware and tend to guide their children on the appropriate period of use $[63,66]$ and suitable apps and websites to access [64,67]. Contrary to this, several studies reported there was no effect of the parent's educational level on problematic mobile device use [44,58].

Household income is a crucial aspect in influencing an individual's life, as well as young children. There are many things that parents can provide to their children with money, including personal mobile devices and internet access. Having a mobile device makes it difficult for parents to monitor usage, which, in turn, contributes to excessive use. Because of this, many studies have reported that children with high household incomes are prone to problematic mobile device use [68-71]. However, [44,58] reported that there was no effect of household income on problematic mobile device use.

Existing studies have reported that there is a significant relationship between frequent types of application usage with excessive mobile device use. Children that used a mobile device for entertainment purposes, such as for playing games [11,72-74], viewing television [75], and communication [76,77], were more likely to be problematic users. Meanwhile, children that used a mobile device for educational-related purposes were not problematic users [74]. However, there are limited studies examining the relationship between children's ages when they start using a mobile device, the purpose of giving mobile devices to children, and problematic mobile device use.

The Malaysian National Population and Family Development Board [78] reported that $78.3 \%$ of parents in Klang Valley allow their children to own mobile devices. In addition, the report stated that $50.1 \%$ of those children spend more than three hours per day on a mobile device, and $29 \%$ are problematic users. Even more worrying is that parents provide and allow children to use mobile devices to keep them inactive for parents to easily conduct housework, to calm children whenever they are throwing tantrums, and to control children's behavior if they are in someone else's house or in a restaurant.

Considering the inconsistent findings and limited data from previous research, the predictive factors of excessive mobile device use in Malaysia are questionable. Thus, the predictive factors for the Malaysian population may be different from those reported in other populations. Therefore, the following hypothesis was proposed in this study:

Hypothesis 1 (H1): Sociodemographic factors significantly contribute to excessive mobile device use among young children.

\section{Materials and Methods}

\subsection{Study Design}

This study employed a cross-sectional survey study design with a quantitative approach. The design and approach of this research were chosen as data could be obtained quickly for a large study sample size. 


\subsection{Participants}

A total of 364 respondents participated in this study. A total of $51.6 \%(n=188)$ of the children were girls, and $48.4 \%(n=176)$ were boys. In terms of age, $51.1 \%(n=186)$ of the children were 5 years old, and $48.9 \%(n=178)$ were 6 years old. In addition, approximately $53.3 \%(n=194)$ of parents were aged 36 years and above, $45.9 \%(n=167)$ were aged between 26 and 35 years, and $0.8 \%(n=3)$ were aged 25 years and below. Regarding the level of education, $35.7 \%(n=130)$ of parents had a bachelor's degree, $25.0 \%(n=91)$ had a certificate, $21.4 \%(n=78)$ had a diploma, and $17.9 \%(n=65)$ had a postgraduate degree. In this study, a certificate refers to a person with a Malaysian Certificate of Education (SPM). In Malaysia, citizens will sit for the Malaysian Certificate of Education examination in the final year of high school. A citizen who fulfills the SPM requirements will be awarded a certification. Meanwhile, a diploma refers to the tertiary education program attended by citizens after receiving an SPM. The duration for a diploma education is three years.

Furthermore, information on household income was also collected to ensure the child participants for this study came from each economic group. In Malaysia, economic status is divided into three categories, namely, the Top 20 (T20), Middle 40 (M40), and Bottom 40 (B40) [79]. T20 refers to Malaysian citizens earning more than MYR 9620 per month (approximately USD 2287.86). This group makes up $20 \%$ of the population in Malaysia. M40 refers to a middle-class group with a monthly household income ranging from MYR 4360 to MYR 9616 (approximately USD 1036.91-2286.91). This group makes up $40 \%$ of the population in Malaysia. Meanwhile, B40 refers to a group of citizens earning less than MYR 4360 for a monthly (approximately USD 1036.91) household income. This group makes up $40 \%$ of the population in Malaysia. Approximately $36.0 \%(n=131)$ of the children came from the M40 group, 33.2\% $(n=121)$ from the T20 group, and $30.8 \%(n=112)$ from the B40 group. Table 1 presents the demographic information on the children and their families.

Table 1. Demographic information on the children and their families.

\begin{tabular}{llc}
\hline Variables & Categories & $\boldsymbol{n}(\mathbf{\%})$ \\
\hline Children's Characteristics & & \\
Gender & Male & $176(48.4)$ \\
& Female & $188(51.6)$ \\
Age (years) & 5 & $186(51.1)$ \\
Family Characteristics & 6 & $178(48.9)$ \\
Age (years) & 25 and below & \\
& $26-35$ & $3(0.8)$ \\
Household income & 36 and above & $167(45.9)$ \\
& T20 & $194(53.3)$ \\
& M40 & $121(33.2)$ \\
Level of education & B40 & $131(36.0)$ \\
& Certification & $112(30.8)$ \\
& Diploma & $91(25.0)$ \\
& Bachelor's degree & $78(21.4)$ \\
& Master's/doctoral degree & $130(35.7)$ \\
\end{tabular}

An analysis was performed to gather information on mobile device use by children. In this study, $72.8 \%(n=265)$ of the children were smartphone users, and $27.2 \%(n=99)$ of the children were tablet users. Approximately 83.2\% $(n=303)$ of the children started using a mobile device at the age of 3 years old and below, and 16.8\% $(n=61)$ started at the age of 4-6 years old. Regarding the types of application, $80.5 \%(n=293)$ of the children used mobile devices for entertainment purposes such as playing games, web surfing, listening to music, or watching videos. Meanwhile, $19.5 \%(n=71)$ of children used mobile devices for educational-related purposes. Analysis of the item, namely, mobile device ownership, showed that $78.8 \%(n=287)$ of the children used their parents' devices, $11.8 \%(n=43)$ of 
the children used other family members' devices, and only $9.3 \%(n=34)$ of the children had their own devices. Parents were also asked about the purposes of providing mobile devices to their children. Approximately $34.1 \%(n=124)$ of parents allowed them to use it for educational purposes, $32.7 \%(n=119)$ of parents responded that they allowed them to use it to make their child sit still, $22.5 \%(n=82)$ of parents allowed their children to use it to be up-to-date with technology, and $10.7 \%(n=39)$ of parents provided mobile devices to avoid and to calm down tantrums. Table 2 presents detailed information on the uses of mobile devices.

Table 2. Mobile device usage information.

\begin{tabular}{llc}
\hline Variables & Categories & $n \mathbf{( \% )}$ \\
\hline Types of device & Smartphone & $265(72.8)$ \\
& Tablet & $(27.2)$ \\
Age at start of use (years) & 3 and below & $303(83.2)$ \\
& $4-6$ & $61(16.8)$ \\
Type of application & Education & $71(19.5)$ \\
& Entertainment & $293(80.5)$ \\
Ownership & Self-owned & $34(9.3)$ \\
& Parents & $287(78.8)$ \\
& Family members & $43(11.8)$ \\
The purpose of providing a mobile device & Sit still & $119(32.7)$ \\
& Tantrums & $39(10.7)$ \\
\end{tabular}

\subsection{Procedure}

Before the data collection process, an application to conduct a study was made to the ethics committee from the Faculty of Education, Universiti Kebangsaan, Malaysia. The approval was received on 9 October 2019. Later, a letter of permission to distribute the questionnaire was given to the owner of the early childhood center. This study was conducted in Putrajaya, Malaysia, due to the diverse backgrounds of the population in terms of education levels and household income. According to data from the Department of Statistics Malaysia, there were 6200 children aged five to six years residing in Putrajaya in 2020. The sample size was estimated using a table from [80]. Based on the table, the actual sample size for this study was 364. A simple random sampling technique was employed in the data collection process. Questionnaires together with an information consent letter were distributed to parents through the school, and a total of 364 questionnaires were collected with a $100 \%$ return rate.

\subsection{Instrument}

This study used a questionnaire for the data collection process. The questionnaire consisted of two sections, namely, demographic information of the participants and the mobile devices use scale. The items for the mobile device use scale sections were adapted from previous research that used the Problematic Mobile Phone Use Scale (PMPUS) [81]. The original instrument consisted of four subdimensions with 26 items and was distributed to university students. The four subdimensions were deprivation, adverse outcomes, control problems, and interaction avoidance. Deprivation evaluates feelings such as anxiousness or uneasiness when the mobile device is not available or not in a usable state; adverse outcomes assess the negative effect of mobile device use on an individual's daily life; control problems measure an individual's ability to control their use of mobile devices; interaction avoidance determines the communication preferences either via online or faceto-face interactions [81]. The original instrument consisted of eight items that measure deprivation (labeled D1, D2, D3, D4, D5, D6, D7 and D8), seven items that measure adverse outcomes (labeled AO9, AO10, AO11, AO12, AO13, AO14 and AO15), six items that measure control problems (labeled as CP16, CP17, CP18, CP19, CP20, and CP21), and five 
items that measure interaction avoidance (labeled as IA22, IA23, IA24, IA25 and IA26). The items were measured using a five-point Likert-type scale, and the response options were: $1=$ not appropriate at all; 2 = rarely appropriate; $3=$ somewhat appropriate; $4=$ fairly appropriate; $5=$ completely appropriate.

Cross-cultural adaptation guidelines were applied by taking into account the translation process and cultural appropriateness $[82,83]$. The translation process aimed to ensure that the instrument was acceptable and relevant for use by the Malaysian population [84-86]. The instrument was translated into the Malay language by a Malay-English speaker. Then, two linguists examined the semantic equivalence of the instrument between the original version and the Malaysian version. Later, a back-translation procedure was performed by a Malay-English speaker who did not know the original version of the instrument. The back-translation process took two weeks. The development of this instrument is explained in Sections 3.4.1 and 3.4.2, and the list of adapted items is outlined in Appendix A.

\subsubsection{Validity and Reliability}

Three experts in early childhood education, psychology, and family counseling evaluated the content validity, culture, and age appropriateness of the adapted version of the PMPUS. A focus group discussion session was conducted with all experts, and they recommended that eight items be removed due to the fact of issues such as irrelevance and repetition. Five items were identified as not appropriate for use with children aged five-to-six years. Moreover, the experts also agreed that it would be difficult for parents to observe the following behavior in children: "my child feels insecure without a mobile device" (D4); "my child will feel lonely without a mobile device" (D7); "my child will feel lost without a mobile device" (D8); "my child is always checking mobile devices" (CP18); "my child wants to use a mobile device again immediately after they stop it" (CP21). Item IA26 (i.e., "my child would rather make friends through social media than real life") was also removed. Experts pointed out that the majority of children in Malaysia aged five to six still do not own social media accounts.

Furthermore, experts also suggested that two items be removed due to the fact of repetition. One of the items was "my child is too busy using a mobile device, which interferes with his daily routine" (AO9). The experts agreed that this question was also asked in AO10 to AO13, which asked about children's mealtimes, sleep habits, and learning activities, referring to their daily routine. The second item removed was "my child is busy using a mobile device so that he is less sociable with the people around him" (AO15). According to experts, this item has the same meaning as the item "my child would rather spend time with a mobile device than hang out with people around him" (AO14). Both items measured children's social interactions and communication with people around them. In addition, the experts also commented on the sentence structure so as to enhance comprehension and clarity. All comments were taken into account to improve the quality of the items. Then, the content validity index (CVI) was calculated using the formula in [87]. The CVI value for this instrument was 0.90 . According to [88], a CVI $\geq 0.80$ is acceptable.

Initially, the adapted version of the PMPUS consisted of 18 items with a five-point Likert scale and the responses $1=$ never, $2=$ rarely, $3=$ sometimes, $4=$ very often, and $5=$ always The Likert scale responses were altered to ensure they were appropriate for the items and participants completing the questionnaire. Compared to the original version, which could be completed by the respondents themselves, this adapted version was prepared to be completed by the parents. Moreover, it was impossible to distribute questionnaires to children aged five-to-six years due to the fact of their lack of comprehensibility. However, the constructs were retained to be the same as the original instrument. The scores were calculated based on the response from the respondent for each item. The minimal score was 18, and the maximum score was 90. An increasing score showed that the person's level of problematic mobile device use was rising [81]. Later, total scores were calculated, and four user categories were determined based on cut-off points as performed in [21], considering the 95th, 80th, and 15th percentiles. Four categories were established, namely, 
casual user, regular user, at-risk user, and problematic user. Table 3 presents information on the user categories, percentiles, and scores ranges.

Table 3. User categories and scores ranges.

\begin{tabular}{lcc}
\hline User Categories & Percentile & Score Ranges \\
\hline Casual user & Below 15th & $18-24$ \\
Regular user & 15th to below 80th & $25-45$ \\
At-risk user & 80th to below 95th & $46-55$ \\
Problematic user & 95th or above & $56-90$ \\
\hline
\end{tabular}

Item reliability measures were performed using Cronbach's alpha. The Cronbach's alpha values obtained ranged from 0.899 to 0.909 . Overall, the Cronbach's alpha value for the adapted version of the PMPUS was $\alpha=0.904$. This demonstrated that the adapted instrument had a good degree of internal consistency. Detailed analysis of each item showed higher scores in items CP17 "my child uses a mobile device beyond the set period" $(M=2.431, S D=1.028)$ and $C P 20$ "my child will look for a mobile device as soon as he wakes up" $(M=2.586, S D=1.026)$. Table 4 presents the mean, standard deviation $(S D)$, and Cronbach's alpha values of the items.

Table 4. Descriptive analysis and internal consistency of items via Cronbach's alpha coefficients.

\begin{tabular}{cccc}
\hline Items & $\boldsymbol{M}$ & $\boldsymbol{S D}$ & Cronbach's Alpha Value if the Item is Removed \\
\hline D1 & 2.286 & 0.982 & 0.904 \\
D2 & 2.176 & 0.957 & 0.901 \\
D3 & 2.258 & 0.939 & 0.903 \\
D5 & 2.211 & 0.879 & 0.901 \\
D6 & 1.550 & 0.761 & 0.899 \\
AO10 & 2.160 & 0.997 & 0.905 \\
AO11 & 1.830 & 0.911 & 0.905 \\
AO12 & 1.717 & 0.833 & 0.902 \\
AO13 & 1.750 & 0.772 & 0.898 \\
AO15 & 1.945 & 0.904 & 0.906 \\
CP16 & 2.264 & 0.969 & 0.909 \\
CP17 & 2.431 & 1.028 & 0.899 \\
CP19 & 1.876 & 0.874 & 0.900 \\
CP20 & 2.586 & 1.026 & 0.912 \\
IA22 & 1.931 & 0.752 & 0.905 \\
IA23 & 1.631 & 0.678 & 0.907 \\
IA24 & 2.184 & 0.931 & 0.909 \\
IA25 & 1.720 & 0.730 & 0.907 \\
\hline
\end{tabular}

$M=$ mean; $S D$ = standard deviation.

\subsubsection{Demographic Information}

The demographic information of the respondents consisted of three sub-sections, namely, child characteristics, family characteristics, and mobile device information. A total of ten items were asked based on three sub-sections: child's gender, child's age, parent's age, household income, parent's level of education, types of mobile devices, child's age at the start of mobile device usage, frequent types of applications used, and the purpose of the mobile device's provision.

\subsection{Analysis}

The analysis was conducted using SPPS ${ }^{\circledR}$ version 26.0 for Windows ${ }^{\mathrm{TM}}$ (IBM Corporation, New York, NY, USA). Descriptive statistical analysis was performed to collect information on the frequency, mean, standard deviation, and mode. Inferential statistical analysis used binary logistic regression to examine the influence of demographic variables, namely, gender, the child's age when starting to use a mobile device, parent's level of education, household income, types of mobile devices, types of applications, and the purpose of 
providing mobile devices to the child. The four categories of mobile device users were transformed into two groups to enable binary logistic regression to be carried out as suggested in $[32,45]$. This was performed by considering the sum of the at-risk users and problematic users as users with a problem. Meanwhile, the sum of the casual users and regular users was considered as users without a problem. Before data analysis, a data-screening process was conducted to ensure the data were clean and free from errors [89].

\section{Results}

\subsection{Exploratory Factor Analysis (EFA)}

Exploratory factor analysis was employed, and the principal axis factoring method with varimax rotation was performed to compute the underlying structure of the 18 items of the adapted instrument. Bartlett's test of sphericity $\left(\chi^{2}=3023.030, p=0.000\right)$ indicated that the variables were correlated highly enough to provide a reasonable basis for factor analysis. Meanwhile, the Kaiser-Meyer-Olkin measure of 0.909 indicated adequate items for each factor. Four factors were studied based on the number of the constructs, namely, deprivation (Factor 1), adverse outcomes (Factor 2), interaction avoidance (Factor 3), and control problems (Factor 4). After rotation, the first factor accounted for $16.46 \%$ of the variance, the second factor accounted for $14.50 \%$, the third factor accounted for $13.11 \%$, and the fourth factor accounted for $9.60 \%$. Table 5 presents the items and factor loadings for the rotated factors, with a loading less than 0.30 excluded to improve clarity.

Table 5. Factor loading from the principal axis factor analysis with varimax rotation for a four-factor solution and adapted PMPUS $(n=364)$.

\begin{tabular}{|c|c|c|c|c|c|}
\hline \multirow{2}{*}{ Items } & \multicolumn{4}{|c|}{ Factor Loading } & \multirow{2}{*}{ Communality } \\
\hline & 1 & 2 & 3 & 4 & \\
\hline $\mathrm{AO} 12$ & 0.764 & & & & 0.657 \\
\hline AO13 & 0.738 & & & & 0.659 \\
\hline AO11 & 0.733 & & & & 0.631 \\
\hline AO10 & 0.525 & & & & 0.525 \\
\hline AO15 & 0.443 & & & & 0.480 \\
\hline D2 & & 0.792 & & & 0.720 \\
\hline D3 & & 0.760 & & & 0.653 \\
\hline D1 & & 0.756 & & & 0.652 \\
\hline D6 & & 0.588 & & & 0.510 \\
\hline D5 & & 0.573 & & & 0.507 \\
\hline IA22 & & & 0.754 & & 0.691 \\
\hline IA25 & & & 0.656 & & 0.517 \\
\hline IA23 & & & 0.628 & & 0.557 \\
\hline IA24 & & & 0.494 & & 0.390 \\
\hline CP17 & & & & 0.549 & 0.368 \\
\hline CP16 & & & & 0.475 & 0.364 \\
\hline CP20 & & & & 0.459 & 0.382 \\
\hline CP19 & & & & 0.449 & 0.400 \\
\hline Eigenvalues & 2.962 & 2.611 & 2.360 & 1.729 & \\
\hline$\%$ of variance & 16.457 & 14.504 & 13.109 & 9.603 & \\
\hline
\end{tabular}

\subsection{User Categories}

The result showed that $64.3 \%(n=234)$ of the children were regular users with an average score of $35.46(S D=5.33)$. In addition, $17.6 \%(n=64)$ of the children were at-risk users with an average score of $48.59(S D=2.34)$. Moreover, $14.8 \%(n=54)$ of the children were casual users with an average score of $21.52(S D=2.13)$. Problematic users were represented by $3.3 \%(n=12)$ of the children with an average score of $59.50(S D=2.72)$. Table 6 presents detailed information on the analysis of user categories. 
Table 6. Percentage of users based on category.

\begin{tabular}{lcccc}
\hline User Categories & $\boldsymbol{n}$ & $\mathbf{\%}$ & $\boldsymbol{M}$ & $\boldsymbol{S D}$ \\
\hline Casual users & 54 & 14.8 & 21.52 & 2.13 \\
Regular users & 234 & 64.3 & 35.46 & 5.33 \\
At-risk users & 64 & 17.6 & 48.59 & 2.34 \\
Problematic users & 12 & 3.3 & 59.50 & 2.72 \\
\hline
\end{tabular}

$M=$ mean; $S D$ = standard deviation.

\subsection{Predictive Sociodemographic Factors of Mobile Device Use}

The four categories of mobile devices users were transformed into two groups, namely, users without a problem and users with a problem. This was performed by joining the existing categories. The at-risk users and problematic users combined to form a group of users with a problem $(20.9 \%)$.+ Meanwhile, casual users and regular users combined to form a group of users without a problem (79.1\%). Binary logistic regression was performed to assess the effect of gender, child's age when starting to use a mobile device, parent's level of education, household income, types of mobile devices, types of applications, and the purposes of providing mobile devices to the child on the likelihood that children become users with a problem.

The model containing all predictors was statistically significant $\chi^{2}(7, n=364)=33.20$, $p=0.002$, indicating that the model was able to distinguish between users with a problem and users without a problem. The model explained between $8.7 \%$ (Cox and Snell $R$ square) and $13.6 \%$ (Nagelkerke $R$ squared) of the variance in mobile device use and classified $77.7 \%$ of cases correctly. The Hosmer-Lemeshow tested the null hypothesis in which the predictions made by the model fitted perfectly with the observed group membership. A Chisquare statistic was computed by comparing the observed frequencies with those expected under the linear model. The chi-square value was 3.564 with $p=0.894$. A non-significant chi-square indicates that the data fit the model well.

As shown in Table 7, three independent variables made unique statistically significant contributions to the model, namely, gender, the child's age at start of use of a mobile device, and the purposes of providing mobile devices to the child. Boys were 0.470 times more likely to become users with a problem than girls. Meanwhile, children introduced to mobile devices at an earlier age were more likely to become users with a problem ( 0.262 times). The purpose of providing mobile devices to make the children sit still was 1.142 times, which may make children become users with a problem. Based on the binary logistic analysis, the regression equation model for this study was:

Table 7. Binary logistic regression analysis for potential factors for problematic users.

\begin{tabular}{|c|c|c|c|c|c|c|c|c|}
\hline \multirow{2}{*}{$\begin{array}{l}\text { Independent } \\
\text { Variables }\end{array}$} & \multirow{2}{*}{$\beta$} & \multirow{2}{*}{$\mathrm{SE}$} & \multirow{2}{*}{ Wald } & \multirow{2}{*}{ df } & \multirow{2}{*}{$p$} & \multirow{2}{*}{ Odds Ratio } & \multicolumn{2}{|c|}{$95 \%$ for OR } \\
\hline & & & & & & & Lower & Upper \\
\hline Gender & -0.755 & 0.280 & 7.288 & 1 & 0.007 ** & 0.470 & 0.272 & 0.813 \\
\hline Age & -1.341 & 0.500 & 7.179 & 1 & 0.007 ** & 0.262 & 0.098 & 0.698 \\
\hline Education & & & 2.530 & 3 & 0.470 & & & \\
\hline Certification & -0.568 & 0.401 & 2.011 & & 0.156 & 0.567 & 0.258 & 1.242 \\
\hline Diploma & -0.547 & 0.423 & 1.672 & & 0.196 & 0.579 & 0.252 & 1.326 \\
\hline Bachelor's & -0.362 & 0.470 & 0.592 & & 0.442 & 0.696 & 0.277 & 1.750 \\
\hline Income & & & 1.822 & 2 & 0.402 & & & \\
\hline B40 & -0.497 & 0.371 & 1.791 & & 1.181 & 0.608 & 0.294 & 1.260 \\
\hline M40 & -0.278 & 0.432 & 0.413 & & 0.520 & 0.758 & 0.325 & 1.767 \\
\hline Types of & 0.114 & 0.319 & 0.127 & 1 & 0.721 & 1.121 & 0.600 & 2.094 \\
\hline Application & 0.206 & 0.366 & 0.318 & 1 & 0.573 & 1.229 & 0.600 & 2.517 \\
\hline Purpose & & & 10.334 & 3 & 0.016 ** & & & \\
\hline Tantrums & 1.142 & 0.428 & 7.122 & & 0.008 ** & 3.1354 & 1.354 & 7.254 \\
\hline Education & -0.237 & 0.350 & 0.456 & & 0.499 & 0.789 & 0.397 & 1.569 \\
\hline Technology & 0.80 & 0.376 & 0.045 & & 0.832 & 1.083 & 0.519 & 2.260 \\
\hline Constant & -1.141 & 0.705 & 0.040 & & 0.841 & 0.868 & & \\
\hline
\end{tabular}

Mobile Devices Users $=-1.141+(-0.755)$ gender $+(-1.341)$ age when starting to use mobile device $+(1.142)$ the purposes of providing mobile devices to the children. 


\section{Discussion}

This study showed that the use of mobile devices among young children in Putrajaya may not be alarming. with the number of users for each category as follows: casual users $=14.8 \%(n=54)$, regular users $=64.3 \%(n=234)$, at-risk users $=17.6 \%(n=64)$, and problematic users $=3.3 \%(n=12)$. Meanwhile, the cumulative percentage of users without a problem was $79.1 \%(n=288)$ and users with problem was $20.9 \%(n=76)$. Although the percentage of users with a problem could be considered small, it should be given attention. It is possible that the percentage of users with a problem will increase without proper monitoring and guides provided.

These findings contrast with the current scenario in other countries. Scholars reported that children's dependence on mobile devices has increased in the last three-to-four years, especially for primary school children in developed countries [90,91]. This difference may exist due to the status as a developed country, which leads to accessibility to high technology infrastructure [5], as it experienced a technological revolution earlier than developing countries such as Malaysia. It is reported that the usage of mobile devices among children below eight years old increased from 34\% in 2011 to $72 \%$ in 2013 [92].

In addition, user categories were also closely related to children's environment involving their microsystems such as parents and siblings. This study can infer that the use of mobile devices among young children in Putrajaya is still under control. Parents play a role in creating a conducive environment for the use of the mobile device by providing guidance and instruction to children. The use of mobile devices by children needs to be properly controlled by parents, especially the duration and purpose of use so that children's development takes place holistically [91-94]. In addition, it helps children avoid using mobile devices excessively.

Children who always use a mobile device will begin to feel comfortable using it without socializing with others [95]. Therefore, this characteristic was similar to the impulsiveantisocial pathway pattern as described in the model of Mobile Phone Use Problem Patterns. This characteristic is related to individuals with mobile phone use problems. They have impulsive actions and low self-control power, which, in turn, results in the use of the device not being well-controlled.

The results of the binary logistic regression analysis showed that three out of seven independent variables of demographic factors had a significant influence on children's mobile devices use. The three independent variables were gender, the child's age when starting to use mobile devices, and the purpose of the parent providing a mobile device to the child. A total of $13.6 \%$ of the variance in becoming problematic users was explained by gender, age, and purpose. The remaining $86.4 \%$ contributed to other factors.

Based on the results of the analysis, gender had a significant influence on patterns of mobile device use. Boys were more likely to be problematic users with a factor of -0.755 . This finding is consistent with other studies $[44,46,60,96,97]$ that reported boys were more prone to excessive mobile device use, while several studies reported the opposite $[45,74]$. However, the majority of these studies were conducted on adolescent and adult populations. Boys and girls have different preferences in using mobile devices. Boys spend more time on mobile devices to play games and girls use them for social media $[44,60]$. These preferences explain the differences in the findings in this research. In Malaysia, children aged five to six rarely have social media accounts. Therefore, girls did not use mobile device for a longer duration than boys.

This study also found that the age of children introduced to mobile devices contributed significantly to user with problem with a factor of -1.341 . Children who are exposed and allowed to use their mobile devices earlier will be susceptible to becoming users with problem. Children's dependence on mobile devices will increase as they become more comfortable with it and less interested in making social connections with peers or family members [23]. In addition, children will see mobile devices as their source of happiness.

The purpose of parents providing mobile devices to their children to make their children sit still significantly contributed to users with problem with a factor of 1.142 . 
Meanwhile, other purposes did not significantly contribute to users with problem. In Malaysia, it is common for parents to provide mobile devices to their children while having mealtimes at the dining table. The purpose is to make sure the children sit still while waiting for the food to be served. Some of them continue to use a mobile device while eating.

This study also showed that the parent's level of education did not significantly contribute to the problem of mobile device use. This suggested that children have the same patterns of mobile device use despite having parents from different educational level backgrounds. This finding contradicts previous studies [69,98-100] that indicated that the highest level of parental education contributed to users with a problem. Putrajaya is an administrative district of the Malaysian government, and the majority of its residents are government employees. As employees, parents in this study had to use computers and technology daily. They can be classified as parents knowledgeable about technology. Therefore, they can monitor, support, and guide their children to use mobile devices and technology positively. In this modern era, everyone can find information about the advantages and disadvantages of excessive mobile device use through the internet. Knowledgeable parents can assist their children in selecting age-appropriate and developmentally appropriate applications that can benefit children [101]. Children who receive positive guidance about mobile device use tend to have positive perceptions towards the use of technology in daily life $[47,62,102-106]$.

The results of binary logistic regression showed that household income did not significantly contribute to excessive mobile device use. This finding explained that children exhibit similar patterns of mobile device use regardless of their family's economic status. This is contrary to previous research $[68,70,71,107-109]$ reporting that household income significantly contributed to excessive mobile device use. Typically, high-income parents can afford to provide mobile devices together with internet access for their children. Availability and accessibility to a mobile device and the internet make children more vulnerable to excessive use of mobile devices.

However, the research findings provided a different explanation. In Malaysia, mobile devices can be purchased at low prices and also provide the facility to download applications for free with the availability of the internet. Because of this, every family can provide mobile devices for use by their children. However, an internet subscription is relatively expensive, and some families cannot afford to subscribe to Wi-Fi at home or have unlimited internet access on their mobile devices [109]. Internet access limitations cause children to only be able to access certain applications and, thus, reduce their interest in mobile devices.

\subsection{Implications}

The preventive measure should take into consideration to ensure the percentage of users with a problem is not increased. This can be achieved by taking into account the sociodemographic factors that proved to significantly contribute to the excessive mobile device use in this study. Therefore, this subtopic discusses the implications of this study. The findings of this study can be used as additional information in drafting a guideline on the mobile device used specifically for young children by the government and stakeholders. The information on the positive relationship between the child's gender, the child's age when starting to use a mobile device, and the purposes of giving a mobile device to the child with excessive mobile device use could be included in the guidelines. In addition, the guideline may propose a suitable age range to introduce and allow children to use the mobile device.

Then, the information on the guidelines could be conveyed to the parents, community, and early childhood educators through an awareness campaign at the national level. Thereby, parents will be more alert regarding the suitable age to introduce the mobile device to their children, did not use a mobile device as calming object whenever their children throw a tantrum, and give more attention to a boy who uses a mobile device than a girl. In addition, parents should also provide a balance of activities children's daily so that they can grow holistically. 


\subsection{Limitations and Scope of Future Research}

Even though this study was conducted with meticulous detail, some limitations still exist. Firstly, there are limitations regarding the location and sample selection. This study involves 364 participants who reside in Putrajaya. Putrajaya is the administrative center of the government of Malaysia and considered an urban area. Moreover, the majority of its residents are government servants. Thus, it is suggested that future studies involve parents and children from all states in Malaysia including suburban and rural areas, and parents from various fields of employment. Thereby, the finding could be generalised to the Malaysian population.

In addition, it is recommended that a future study take into account the race information of the participant. Malaysia is a multiracial country, and every family from a different race is practicing different norms and values in their daily life including the way of raising a child. It could be interesting to investigate the differences in mobile device practices based on race factors. A previous study from Singapore reported Malay and Indian children occupy significantly more time on mobile device activity compared to Chinese children [110]. Therefore, future studies may address the differences in the way parents provide guidance and monitor their children's mobile device use. The positive aspect of guiding and monitoring could be useful and applicable for other parents.

Secondly, regarding the validity and reliability of the items in the adapted version of the Problematic Mobile Phone Use Scale (PMPUS). This research examines the validity and reliability of the items by performing exploratory factor analysis (EFA) and determining the value of the content validity index and Cronbach's alpha. Therefore, a future study can broaden the item assessment by performing Rasch analysis and confirmatory factor analysis (CFA). Rasch analysis is an advanced approach used to enhance the accuracy of instruments development, monitor instrument quality, and compute participants' performances [111]. Meanwhile, confirmatory factor analysis was used to verify the number of underlying dimensions of the instrument and the pattern of item-factor relationships. Rasch analysis will provide comprehensive information on items properties, and confirmatory factor analysis will reveal to what extent the subdimension measures the variables.

Thirdly, this study employed a cross-sectional research design, and data were collected using a questionnaire. Although the data collected are credible to explain the causal relationship between the variables, the data may not be able to explain the reason for such a relationship existing [112]. This issue can be overcome by employing a mixed-method research design and collecting quantitative and qualitative data. Qualitative data from interviews and observation may help in providing useful information and explanation of the effects of sociodemographic factors on mobile device usage.

Lastly, this study only examines the direct relationship between sociodemographic factors and excessive mobile device use of young children. However, future study may include the potential mediator variables in order to provide more meaningful findings. The mediator variables will reveal how the mediator affects the strength of the relationship between sociodemographic factors and excessive mobile device use. The potential mediator variable that can be applied is the period of using a mobile device.

\section{Conclusions}

This study investigated the category of mobile device users among young children in Putrajaya, Malaysia. In addition, this study also examined the influence of sociodemographic factors, namely, gender, the child's age when starting to use a mobile device, parent's level of education, monthly household income, frequent types of applications, and the purpose of giving mobile devices to young children. The findings of this study show that the majority of participants were regular users, followed by the at-risk user, casual user, and problematic user. Analysis of the influences of sociodemographic factors revealed that gender, age of children when starting to use mobile devices, and the purpose of providing mobile devices to children contributed significantly to excessive mobile use by young children. Based on the findings of this study, parents should create a healthy 
environment on a mobile device by providing guidance and monitoring the duration and content of the applications used by children. Next, these sociodemographic factors can be taken into account when planning for intervention or guidance programs on mobile device use, especially for young children.

Author Contributions: N.N.A., S.M., K.A.B. and N.S. were responsible for the concept and design of this study; N.N.A. was involved in data collection; N.N.A., S.M., K.A.B. and N.S. conducted the statistical analysis and contributed to the interpretation of the findings; N.N.A. wrote the first draft of the paper; S.M. made critical revisions. All authors have read and agreed to the published version of the manuscript.

Funding: This study was funded by the Faculty of Education, Universiti Kebangsaan Malaysia through the Dana Khas Galakkan Penyelidikan. The title of research is The Development of SocialEmotional Learning Module for Preschooler (Pembangunan Modul Pembelajaran Sosioemosi untuk Kanak-Kanak Prasekolah) with research code, GG-2020-017.

Institutional Review Board Statement: The study was conducted according to the guidelines of the Declaration of Helsinki and approved by Faculty of Education, Universiti Kebangsaan Malaysia (UKM FND/P93570).

Informed Consent Statement: Informed consent was obtained from all the subjects involved in the study.

Data Availability Statement: The data presented in this study are available upon request from the corresponding author. The data are not publicly available due to the risk of the identification of study participants.

Acknowledgments: Special thanks and appreciation to Suziyani Mohamed for her guidance and support.

Conflicts of Interest: The authors declare no potential conflict of interest with respect to the research, authorship, and/or publication of this article.

\section{Appendix A}

Table A1. Adapted Version of PMPUS.

D1. My child will be restless if the mobile device he is using does not have an internet connection D2. My child will be restless if the mobile device he is using runs out of battery

D3. My child will be agitated if the mobile device he is using lags

D5. My child seems unhappy if not given a mobile device

D6. My child finds it difficult to sleep if not given a mobile device

AO10. My child is busy using mobile devices that it interrupts his mealtime routine

AO11. My child is busy using mobile devices that interferes with his sleep routine

AO12. My child is busy using mobile devices that he has trouble completing preschool homework

AO13. My child is busy using mobile devices that he has trouble focusing on learning

AO15. My child is busy using mobile devices that it affects his interaction with the people around him

CP16. My child would have a tantrum if the mobile device he was using was taken away

CP17. My child is using a mobile device beyond the set period

CP19. My child uses a mobile device for more than two hours a day

CP20. My child will look for a mobile device as soon as he wakes up

IA22. My child would rather spend time with a mobile device than hang out with the people around him

IA23. My child prefers to have conversations using a mobile device, rather than face to face

IA24. My child prefers to use a mobile device alone

IA25. My child prefers to play game using a mobile device than play with friends 


\section{References}

1. Noorshahira, M.F.; Mohd Yusof, A.; Mohd Azul, M.S. The level of tolerance sanctioning children using by parents lead to Nomophobia: Early age gadgets exposure. Int. J. Arts Sci. 2016, 9, 615-622.

2. Harris, B.; Regan, T.; Schueler, J.; Fields, S. Problematic mobile phone and smartphone use scales: A systematic review. Front. Psychol. 2020, 11, 672. [CrossRef]

3. Sohn, S.Y.; Rees, P.; Wildridge, B.; Kalk, N.J.; Carter, B. Prevalence of problematic smartphone usage and associated mental health outcomes amongst children and young people: A systematic review, meta-analysis and grade evidence. BMC Psychiatry 2019, 19, 356. [CrossRef]

4. Ilhm, J. Social implications of children's smartphone addiction: The role of support networks and social engagement. J. Behav. Addict. 2018, 7, 473-481. [CrossRef]

5. Statista. Available online: https://www.statista.com/topics/840/smartphones/\#dossierKeyfigures (accessed on 31 December 2021).

6. Chaudron, S.; Di Giola, R.; Gemo, M. Young Children (0-8) and Digital Technology, a Qualitative Study across Europe; European Commission: Luxembourg, 2018. [CrossRef]

7. Marsh, J. Young children's play in online virtual worlds. J. Early Child. Res. 2010, 8, 23-39. [CrossRef]

8. Marsh, J. Unboxing' videos: Co-construction of the child as cyberflaneur. Discourse: Stud. Cult. Politics Educ. 2015, 37, 369-380. [CrossRef]

9. Nikken, P.; Jansz, J. Developing scales to measure parental mediation of young children's internet use. Learn. Media Technol. 2013, 39, 250-266. [CrossRef]

10. Sergi, K.; Gatewood, R.; Elder, A.; Xu, J. Parental perspectives on children's use of portable digital devices. Behav. Inf. Technol. 2017, 36, 1148-1161. [CrossRef]

11. Cha, S.-S.; Seo, B.-K. Smartphone use and smartphone addiction in middle school students in Korea: Prevalence, social networking service and game use. Health Psychol. Open 2018, 5, 2055102918755046. [CrossRef] [PubMed]

12. Miller, G. The smartphone psychology manifesto. Perspect. Psychol. Sci. 2012, 7, 221-237. [CrossRef] [PubMed]

13. Plowman, L.; McPake, J.; Stephen, C. The technologisation of childhood. Young children and technology in the home. Child. Soc. 2010, 24, 63-74. [CrossRef]

14. Radesky, J.S.; Eisenberg, S.; Kistin, C.J.; Gross, J.; Block, G.; Zuckerman, B.; Silverstein, M. Overstimulated consumers or next-generation learners? Parent tensions about child mobile technology use. Ann. Fam. Med. 2016, 14, 503-508. [CrossRef]

15. Alif, L.; Lara, F.; Sofia, H. Influence of gadget usage and parent involvement to children's prosocial behavior. J. Ilm. Pendidik. Dan Pembelajaran 2018, 2, 174-179.

16. Chen, L.; Yan, Z.; Tang, W.; Yang, F.; Xie, X.; He, J. Mobile phone addiction levels and negative emotions among Chinese young adults: The mediating role of interpersonal problems. Comput. Hum. Behav. 2016, 55, 856-866. [CrossRef]

17. Hinkley, T.; Verbestel, V.; Ahrens, W.; Lissner, L.; Molnar, D.; Moreno, L.A.; Pigeot, I.; Pohlabeln, H.; Reisch, L.; Russo, P.; et al. Early childhood electronic media use as a predictor of poorer well-being a prospective cohort study. Jama Pediatrics 2014, 168, 485-492. [CrossRef]

18. Kuss, D.J.; Lopez-Fernandez, O. Internet addiction and problematic internet use: A systematic review of clinical research. World J. Psychiatry 2016, 6, 143. [CrossRef]

19. Chen, X. Culture, Peer Interaction, and Socioemotional Development. Child Dev. Perspect. 2011, 6, 27-34. [CrossRef]

20. Genc, Z. Parents' perceptions about the mobile technology use of preschool aged children. Procedia Soc. Behav. Sci. 2014, 146, 55-60. [CrossRef]

21. Chow, S.L.; Leung, G.M.; Ng, C.; Yu, E. A screen for identifying maladaptive internet. Int. J. Ment. Health Addict. 2009, 7, 324-332. [CrossRef]

22. Claesdotter-Knutsson, E.; Andre, F.; Fridh, M.; Delfin, C.; Hakansson, A.; Lindström, M. Gender-based differences and associated factors surrounding excessive smartphone use among adolescents: Cross-sectional study. JMIR Paediatr. Parent. 2021, 4, e30889. [CrossRef]

23. Wu, Z.; Hu, B.Y.; Fan, X.; Zhang, X. The associations between social skills and teacher-child relationships: A longitudinal study among Chinese preschool children. Child. Youth Serv. Rev. 2018, 88, 582-590. [CrossRef]

24. Chonchaya, W.; Pruksananonda, C. Television viewing associates with delayed language development. Acta Paediatr. 2008, 97, 977-982. [CrossRef] [PubMed]

25. Hamzah, H.; Alexander, L.K. Gadget usage: Trends and its relationship with psychosocial adjustment among pre-schoolers in Malaysia. Int. J. Stud. Child. Women Elder. Disabl. 2018, 5, 93-99.

26. Inoue, S.; Yorifuji, T.; Kato, T.; Sanada, S.; Doi, H.; Kawachi, I. Children's media use and self-regulation behavior: Longitudinal associations in a nationwide Japanese study. Matern. Child Health J. 2016, 20, 2084-2099. [CrossRef]

27. Swing, E.L.; Gentile, D.A.; Anderson, C.A.; Walsh, D.A. Television and video game exposure and the development of attention problems. Pediatrics 2010, 126, 214-221. [CrossRef]

28. Christakis, D.A.; Zimmerman, F.J.; DiGiuseppe, D.L.; McCarty, C.A. Early television exposure and subsequent attentional problems in children. Pediatrics 2004, 113, 708-713. [CrossRef]

29. Conners, N.A.; McKelvey, L. Social outcomes associated with media viewing habits of low-income preschool children. Early Educ. Development 2011, 22, 256-273. [CrossRef] 
30. Van Deursen, A.J.A.M.; Bolle, C.L.; Hegner, S.M.; Kommers, P.A.M. Modeling habitual and addictive smartphone behavior. Comput. Human Behavior 2015, 45, 411-420. [CrossRef]

31. Lee, H.; Kim, J.W.; Choi, T.Y. Risk factors for smartphone addiction in Korean adolescents: Smartphone use patterns. J. Korean Med. Sci. 2017, 32, 1674-1679. [CrossRef]

32. Park, J.H.; Park, M. Smartphone use patterns and problematic smartphone use among preschool children. PLoS ONE 2021, 16, e0244276. [CrossRef]

33. Mira Adila, M.S.; Noor Hafizah, H.; Sulfeeza, M.D. Impact of ICT and electronic gadget among young children in education: A conceptual model in Zulikha. In Proceedings of the 6th International Conference on Computing \& Informatic, Kedah, Malaysia, 21-22 November 2018.

34. Twining, P.; Evans, D.; Cook, D.; Ralston, J.; Selwood, I.; Jones, A.; Underwood, J.; Dillon, G.; Scanlon, E.; Heppell, S.; et al. Tablet PCs in Schools: Case Study Report; Becta: Coventry, UK, 2005.

35. Olson, J.; Codde, J.; de Maagd, K.; Tarkelson, E.; Sinclair, J.; Yook, S.; Egidio, R. An Analysis of e-Learning Impacts E Best Practices in Developing Countries with Reference to Secondary School Education in Tanzania; Michigan State University: East Lansing, MI, USA, 2011

36. Anderson, J. IT, e-learning and teacher development. Int. Educ. J. 2005, 5, 1-14.

37. Fiorini, M. The effect of home computer use on children's cognitive and non-cognitive skills. Econ. Educ. Rev. 2010, 29, 55-72. [CrossRef]

38. Osman, Z. Children's emotional development using Didi \& Friends songs. Natl. J. Early Child. Educ. 2016, 5, 49-60.

39. Joginder Singh, J.; Mohd Azman, F.N.S.; Sharma, S.; Razak, R.A. Malaysian parents' perception of how screen time affects their children's language. J. Child. Media 2021, 15, 588-596. [CrossRef]

40. Abdullah, N.N.; Mohamed, S. Problems of mobile device use among young children. In Proceedings of the Malaysia International Convention on Education Research and Management, Kuala Lumpur, Malaysia, 25 August 2020.

41. Mustafa, N.; Rusali, R.; Ramos, A.A.; Ghazali, J.; Mohd Shukri, N.A. The gadget generation: Boy mass index and duration of physical activity and screen-viewing among preschoolers in Kuantan, Pahang. Malays. J. Public Health Med. 2020, $20,116-122$.

42. Tan, S.Y.; Safinaz, M.K. Impact of screen time on refractive status in children aged 3 to 6 years. Malays. J. Ophthalmol. 2021, 3 , 89-90.

43. Mizhanim, M.S.; Ng, P.L.; Sally, T.P.R.; Norlaili, A. Does screen time affect eye health? Preliminary comparative findings from the Standard Patient Evaluation of Eye Dryness (SPEED) and the Ocular Surface Disease Index (OSDI) questionnaires among young In Proceedings of the 23rd Medical \& Health Research Week, Kuala Lumpur, Malaysia, 16-27 August 2021.

44. Fischer-Grote, L.; Kothgassner, O.D.; Felnhofer, A. Risk factors for problematic smartphone use in children and adolescents: A review of existing literature. Neuropsychiatrie 2019, 33, 179-190. [CrossRef]

45. De-Sola, J.; Talledo, H.; Rodrigurez de Fonseca, F.; Rubio, G. Prevalence of problematic cell phone use in an adult population in Spain as assessed by the Mobile Phone Problem Use Scale (MPPUS). PLoS ONE 2017, 12, e0181184. [CrossRef]

46. Son, H.; Park, S.; Han, G. Gender differences in parental impact on problematic smartphone use among Korean adolescents. Int. J. Environ. Res. Public Health 2021, 18, 443. [CrossRef]

47. Chiang, J.T.; Chang, F.C.; Lee, K.W.; Hsu, S.Y. Transitions in smartphone addiction proneness among children: The effect of gender and use patterns. PLoS ONE 2019, 14, e0217235. [CrossRef]

48. Cocorada, E.; Maican, C.I.; Cazan, A.M.; Maican, M.A. Assessing the smartphone addiction risk and its associations with personality traits among adolescents. Child Youth Serv. Rev. 2018, 93, 345-354. [CrossRef]

49. Randler, C.; Wolfgang, L.; Matt, K.; Demirhan, E.; Horzum, M.B.; Besoluk, S. Smartphone addiction proneness in relation to sleep and morningness-eveningness in German adolescents. J. Behav. Addict. 2016, 5, 465-473. [CrossRef] [PubMed]

50. Choliz, M. Mobile-phone addiction in adolescent: The test of mobile phone dependence (TMD). Prog. Health Sci. 2012, 22, 33-45.

51. Emirtekin, E.; Balta, S.; Sural, I.; Kircaburun, K.; Griffiths, M.D.; Billieux, J. The role of childhood emotional maltreatment and bodyimage dissatisfaction in problematic smartphone use among adolescents. Psychiatry Res. 2019, 271, 634-639. [CrossRef]

52. Lee, S.J.; Lee, C.; Lee, C. Smartphone addiction and application usage in Korean adolescents: Effects of mediation strategies. Soc. Behav. Personal. Int. J. 2016, 44, 1525-1534. [CrossRef]

53. Lopez-Fernandez, O.; Losada-Lopez, J.L.; Honrubia-Serrano, M.L. Predictors of problematic internet and mobile phone usage in adolescents. Aloma Rev. De Psicol. 2015, 33, 49-58. [CrossRef]

54. Seo, D.G.; Park, Y.; Kim, M.K.; Park, J. Mobile phone dependency and its impacts on adolescents' social and academic behaviors. Comput. Hum. Behav. 2016, 63, 282-292. [CrossRef]

55. Yang, Y.S.; Yen, J.Y.; Ko, C.H.; Cheng, C.P.; Yen, C.E. The association between problematic cellular phone use and risky behaviors and low self-esteem among Taiwanese adolescents. BMC Public Health 2010, 10, 217. [CrossRef]

56. De Pasquale, C.; Sciacca, F.; Hichy, Z. Smartphone addiction and dissociative experience: An investigation in Italian adolescents aged between 14 and 19 years. Int. J. Psychol. Behav. Anal. 2015, 1, 109. [CrossRef]

57. Soni, R.; Upadhyay, R.; Jain, M. Prevalence of smart phone addiction, sleep quality and associated behaviour problems in adolescents. Int. J. Res. Med. Sci. 2017, 5, 515-519. [CrossRef]

58. Ayar, D.; Bektas, M.; Bektas, I.; Kudubes, A.A.; Ok, Y.S.; Altan, S.S.; Celik, I. The effect of adolescents' internet addiction on smartphone addiction. J. Addict. Nurs. 2017, 28, 210-214. [CrossRef] [PubMed] 
59. Lee, E.J.; Ogbolu, Y. Does parental control work with smartphone addiction? A cross-sectional study of children in South Korea. J. Addict. Nurs. 2018, 29, 128-138. [CrossRef] [PubMed]

60. Chen, B.; Liu, F.; Ding, S. Gender differences in factors associated with smartphone addiction: A cross-sectional study among medical college students. BMC Psychiatry 2017, 17, 341. [CrossRef]

61. Sanchez-Martinez, M.; Otero, A. Factors associated with cell phone use in adolescents in the community of Madrid (Spain). Cyberpsychology Behav. 2009, 12, 131-137. [CrossRef] [PubMed]

62. Roser, K.; Schoeni, A.; Foerster, M.; Roosli, M. Problematic mobile phone use of Swiss adolescents: Is it linked with mental health or behaviour? Int. J. Public Health 2016, 61, 307-315. [CrossRef]

63. Hesketh, K.; Ball, K.; Crawford, D.; Campbell, K.; Salmon, J. Mediators of the relationship between maternal education and children's TV viewing. Am. J. Prev. Med. 2007, 33, 41-47. [CrossRef]

64. Shirley, S.A.; Kumar, S.S. Awareness and attitude among parents of primary school students towards screen time in children. Int J. Contemp. Pediatrics 2020, 7, 107. [CrossRef]

65. De Craemer, M.; Verloigne, M.; Ghekiere, A.; Loyen, A.; Dargent-Molina, P.; Brug, J.; Lien, N.; Froberg, K.; Wedderkopp, N.; Chastin, S.; et al. Changes in children's television and computer time according to parental education, parental income and ethnicity: A 6-year longitudinal EYHS study. PLoS ONE 2018, 7, 1-13. [CrossRef]

66. Gebremariam, M.K.; Altenburg, T.M.; Lakerveld, J.; Andersen, L.F.; Stronks, K.; Chinapaw, M.J.; Lien, N. Associations between socioeconomic position and correlates of sedentary behaviour among youth: A systematic review. Obes. Rev. 2015, 16, 988-1000. [CrossRef]

67. Alvarez, M.; Torres, A.; Rodriguez, E.; Padilla, S.; Rodrigo, M.J. Attitudes and parenting dimensions in parents' regulation of internet use by primary and secondary school children. Comput. Educ. 2013, 67, 69-78. [CrossRef]

68. Mangan, E.; Leavy, J.E.; Jancey, J. Mobile device use when caring for children 0-5 years: A naturalistic playground study. Health Promot. J. Aust. 2018, 29, 337-343. [CrossRef]

69. Nikken, P.; Schols, M. How and why parents guide the media use of young children. J. Child Fam. Stud. 2015, 24, 3423-3435. [CrossRef] [PubMed]

70. Dimmick, J.; Feaster, J.C.; Hoplamazian, G.J. News in the inter-stices: The niches of mobile media in space and time. New Media Soc. 2011, 13, 23-39. [CrossRef]

71. Oulasvirta, A.; Rattenbury, T.M.L.; Raita, E. Habits make smartphone use more pervasive. Pers. Ubiquitous Comput. 2012, 16, 105-114. [CrossRef]

72. Walsh, S.P.; White, K.M.; Cox, S.; Young, R.M. Keeping in constant touch: The predictors of young Australians' mobile phone involvement. Comput. Hum. Behav. 2011, 27, 333-342. [CrossRef]

73. Liu, C.H.; Lin, S.H.; Pan, Y.C.; Lin, Y.H. Smartphone gaming and frequent use pattern associated with smartphone addiction. Medicine 2016, 95, e4068. [CrossRef] [PubMed]

74. Jeong, S.H.; Kim, H.; Yum, J.Y.; Hwang, Y. What type of content are smartphone users addicted to? SNS vs. games. Comput. Hum. Behav. 2016, 54, 10-17. [CrossRef]

75. Mohammadbeigi, A.; Absari, R.; Valizadeh, F.; Saadati, M.; Sharifimoghadam, S.; Ahmadi, A.; Mokhtari, M.; Ansari, H. Sleep quality in medical students; the impact of over-use of mobile cell-phone and social networks. J. Res. Health Sci. 2016, 16, 46-50. [CrossRef]

76. Lopez-Fernandez, O.; Kuss, D.J.; Romo, L.; Morvan, Y.; Kern, L.; Graziani, P.; Rousseau, A.; Rumpf, H.-J.; Bischof, A.; Gässler, A.-K.; et al. Self-reported dependence on mobile phones in young adults: A European cross-cultural empirical survey. J. Behav. Addict. 2017, 6, 168-177. [CrossRef]

77. Haug, S.; Castro, R.P.; Kwon, M.; Filler, A.; Kowatsch, T.; Schaub, M.P. Smartphone use and smartphone addiction among young people in Switzerland. J. Behav. Addict. 2015, 4, 299-307. [CrossRef]

78. Free Malaysia Today. Available online: https://www.freemalaysiatoday.com/category/bahasa/2019/11/28/hampir-80-ibubapa-lembah-klang-benarkan-anak-guna-gajet/ (accessed on 31 December 2021).

79. Department of Statistic Malaysia. Available online: https:/ /www.dosm.gov.my (accessed on 31 December 2021).

80. Krejcie, R.V.; Morgan, D.W. Determining sample size for research activities. Educ. Psychol. Meas. 1970, 30, 607-610. [CrossRef]

81. Pamuk, M.; Atli, A. Development of a Problematic Mobile Phone Use Scale for University Students: Validity and Reliability Study. J. Psychiatry Neurol. Sci. 2016, 29, 49-59. [CrossRef]

82. Brislin, R.W. Back-translation for cross-cultural research. J. Cross-Cult. Psychol. 1970, 1, 185-216. [CrossRef]

83. Epstein, J.; Santo, R.M.; Guillemin, F. A review of guidelines for cross-cultural adaptation of questionnaires could not bring out a consensus. J. Clin. Epidemiol. 2014, 68, 435-441. [CrossRef] [PubMed]

84. Pereira-Lima, K.; Silva-Rodrigues, A.P.C.; Marucci, F.A.F. Cross-cultural adaptation and psychometric assessment of BrazilianPortugese version of resident questionnaire. PLoS ONE 2018, 13, e0203531. [CrossRef] [PubMed]

85. Gjersing, L.; Caplehorn, J.R.M.; Clausen, T. Cross-cultural adaptation of research instruments: Language, setting, time and statistical considerations. BMC Med. Res. Methodol. 2010, 10, 13. [CrossRef]

86. Herdman, M.; Fox-Rushby, J.; Badia, X. A model of equivalence in the cultural adaptation of HRQoL instruments: The universalist approach. Qual. Life Res. 1998, 7, 323-335. [CrossRef] [PubMed]

87. Polit, D.F.; Beck, C.T. The content validity index: Are you sure you know what's being reported? Critique and recommendations. Res. Nurs. Health 2006, 25, 489-497. [CrossRef] 
88. Davis, R.A. A cognitive-behavioral model of pathological internet use. Comput. Hum. Behav. 2001, 17, 187-195. [CrossRef]

89. Pallant, J. SPSS Survival Manual: A Step-by-Step Guide to Data Analysis Using IBM SPSS, 7th ed.; Open University Press: Berkshire, UK, 2020; pp. 43-50.

90. Choi, D.; Kim, M. Development of youth digital citizenship scale and implication for educational setting. Educ. Technol. Soc. 2018, $27,155-171$.

91. Gold, J. Screen-Smart Parenting: How to Find Balance and Benefit in Your Child's Use of Social Media, Apps, and Digital Devices; The Guilford Press: New York, NY, USA, 2015.

92. Zero to Eight: Children's Media Use in America 2013. Available online: https://www.commonsensemedia.org/zero-to-eight-20 13-infographic (accessed on 31 December 2021).

93. Hendricks, C. Ten ways to help parents navigate technology with children. Child. Libr. J. Assoc. Libr. Serv. Child. 2015, 13, 36-37. [CrossRef]

94. Veldhuis, L.; Van Grieken, A.; Renders, C.M.; HiraSing, R.A.; Raat, H. Parenting style, the home environment, and screen time of 5-year-old children; the 'be active, eat right' study. PLoS ONE 2014, 9, 1-9. [CrossRef] [PubMed]

95. Kim, H.J.; Min, J.Y.; Min, K.B.; Lee, T.J.; Yoo, S. Relationship among family environment, self-control, friendship quality, and adolescents' smartphone addiction in South Korea: Findings from nationwide data. PLoS ONE 2020, 13, 1-13. [CrossRef] [PubMed]

96. Lee, H.; Seo, M.J.; Choi, T.Y. The effect of home-based daily journal writing in Korean adolescents with smartphone addiction. J. Korean Med. Sci. 2016, 31, 764-769. [CrossRef] [PubMed]

97. Lopez-Fernandez, O.; Honrubia-Serrano, M.; Frexia-Blanxart, M. Spanish adaptation of the mobile phone problem use scale for adolescent population. Adicciones 2012, 24, 123-130. [CrossRef] [PubMed]

98. Wu, C.S.T.; Fowler, C.; Winsome, Y.Y.L.; Ho, T.W.; Charmaine, H.M.W.; Alice, Y.L. Parenting approaches and digital technology use of preschool age children in a Chinese community. Ital. J. Pediatrics 2014, 40, 44. [CrossRef]

99. Padilla, S.; Rodriguez, E.; Alvarez, M.; Torres, A.; Suarez, A.; Rodrigo, M.J. The influence of the family educational scenario on internet use of primary and secondary school children. J. Study Educ. Dev. 2015, 38, 402-434. [CrossRef]

100. Csibi, S.; Griffiths, M.D.; Demetrovics, Z.; Szabo, A. Analysis of problematic smartphone use across different age groups within the components model of addiction. Int. J. Ment. Health Addict. 2019, 19, 616-631. [CrossRef]

101. Chiong, C.; Shuler, C. Learning: Is There an App for That? Investigations of Young Children's Usage and Learning with Mobile Devices and Apps; The Joan Ganz Looney Center at Sesame Workshop: New York, NY, USA, 2010; pp. 44-48.

102. Pempek, T.A.; Demers, L.B.; Hanson, K.G.; Kirkorian, H.L.; Anderson, D.R. The impact of infant-directed videos on parent-child interaction. J. Appl. Dev. Psychol. 2011, 32, 10-19. [CrossRef]

103. Izci, B.; Jones, I.; Ozdemir, T.; Alktebi, L.; Bakır, E. Children, Families and Technology in Today's Society: What Challenges? Which Paths? Lisbon School of Education: Lisbon, Portugal, 2019; pp. 81-92.

104. Neumann, M.M. Young children and screen time: Creating a mindful approach to digital technology. Aust. Educ. Comput. 2015, 30, 1-15.

105. Neumann, M.M. Parent scaffolding of young children's use of touch screen tablets. Early Child Dev. Care 2017, 188, 1654-1664. [CrossRef]

106. Anderson, M. Technology Device Ownership. Available online: https://www.pewresearch.org/internet/2015/10/29 /technology-device-ownership-2015/ (accessed on 1 January 2022).

107. Jessie, R.; Jodi, D.; Susan, W.; Jennifer, D. Parents' use of information and communications technologies for family communication: Differences by age of children. Inf. Commun. Soc. 2015, 18, 78-93. [CrossRef]

108. Harmon, E.L.; Mazmanian, M. Stories of the smartphone in everyday discourse: Conflict, tension \& instability. In Proceedings of the SIGCHI Conference on Human Factors in Computing Systems, Paris, France, 23 April 2013. [CrossRef]

109. Mohamed, S.; Toran, H. Family socioeconomic status and social-emotional development among young children in Malaysia. $J$. Appl. Sci. 2018, 18, 122-128. [CrossRef]

110. Benard, Y.B.; Padmapriya, N.; Chen, B.; Cai, S.; Tan, K.H.; Yap, F.; Shek, L.; Chong, Y.-S.; Gluckman, P.D.; Godfrey, K.M.; et al. Predictors of screen viewing time in young Singaporean children: The GUSTO cohort. Int. J. Behav. Nutr. Phys. Act. 2017, 14, 112-121. [CrossRef] [PubMed]

111. Boone, W.J. Rasch analysis for instrument development: Why, when and how? CBE-Life Sci. Educ. 2016, 15, rm4. [CrossRef] [PubMed]

112. Denzin, N.K.; Lincoln, Y.S.; Smith, L.T. Handbook of Critical and Indigenous Methodologies; SAGE Publication Inc.: Thousand Oaks, CA, USA, 2008. 